\title{
TFAP2B Gene
}

National Cancer Institute

\section{Source}

National Cancer Institute. TFAP2B Gene. NCI Thesaurus. Code C28543.

This gene plays a role in regulation of transcription and cell differentiation. It is also involved in apoptosis, cell-cycle control and morphogenesis. 